\title{
IMPLEMENTASI DISCOVERY LEARNING DENGAN \\ BANTUAN PROGRAM CABRI 3D PADA MATERI POKOK \\ DIMENSI TIGA KELAS X-A
}

\author{
Hadi Prasetyo \\ Universitas Islam Negeri Walisongo Semarang \\ Email: prasetyohadi167@gmail.com
}

\begin{abstract}
This article discusses about the application of the discovery learning model supported by Cabri 3D program to improve the learning outcomes of students in the three dimensions subject. This research is motivated by the study of grade $X$ students focused on three-dimensional material in academic year 2013/2014 in which it does not reach KKM rated in 75 point. In this case, only 5 of 54 learners of class $X$ could complete it. Meanwhile, the overall average was 63.06 by $9.26 \%$ as result of the percentage of completeness. It is affected by students who have not mastered the threedimensional concepts and difficulties in abstracting the model or problem in three dimensions.

This study aims to answer the formulation of the problem: could the application of the discovery learning model assisted by Cabri 3D program improve the learning outcomes of students in the subject matter of the three dimensions $X A$ class $M A A l$ Bidayah Candi Bandungan in the academic year 2014/2015. The success of this research is indicated by the improvement of learning outcomes above KKM that is 75 and percentage of students' completeness in each cycle.

This research is included in classroom action research. It is research interests are 20 learners class XA MA Al Bidayah Candi Bandungan District Semarang in the academic year 2014/2015. Data were collected by documentation, observation, and test method. The collected data was analyzed using descriptive analysis to determine the average of learning outcomes and the percentage of learning mastery.

Based on the results of the study, the average result of learning from the first cycle to the second cycle increased from 63.89 to 83.13 or by 19.24 points and mastery learning increased from $38.89 \%$ to $80 \%$ or by $41.11 \%$. Implementation of discovery learning model-assisted learning program Cabri $3 D$ can enhance the learning outcomes of students but not necessarily be able to improve learning outcomes, because it can be affected by various factors such as classroom management, the ability of learners, learners' concentration, accuracy, and so forth. So it is suggested to teachers to do innovative and various learning methods and utilizing media in supporting the learning process.
\end{abstract}

Hadi Prasetyo, Implementasi Discovery... 
Keywords: Discovery learning, cabri 3D, three dimensions

\begin{abstract}
Abstrak
Artikel ini membahas tentang penerapan model pembelajaran discovery learning berbantuan program Cabri 3D untuk meningkatkan hasil belajar peserta didik materi pokok dimensi tiga. Penelitian ini dilatarbelakangi oleh hasil belajar peserta didik kelas $\mathrm{X}$ materi dimensi tiga tahun pelajaran 2013/ 2014 yang kurang dari KKM yaitu 75, dimana dari 54 peserta didik kelas $\mathrm{X}$, hanya ada lima peserta didik yang tuntas, sedangkan rata-rata secara keseluruhan adalah 63,06 dengan persentase ketuntasan sebesar $9,26 \%$. Hal ini disebabkan oleh peserta didik yang belum menguasai konsep-konsep dimensi tiga dan kesulitan dalam mengabstraksi model atau permasalahan pada dimensi tiga.

Penelitian ini bertujuan untuk menjawab rumusan masalah: apakah penerapan model pembelajaran discovery learning berbantuan program Cabri 3D dapat meningkatkan hasil belajar peserta didik materi pokok dimensi tiga kelas X-A MA Al Bidayah Candi Bandungan Tahun Pelajaran 2014/2015. keberhasilan penelitian ini ditunjukkan dengan adanya peningkatan hasil belajar di atas KKM yaitu 75 dan persentase ketuntasan peserta didik pada setiap siklusnya.

Penelitian ini termasuk penelitian tindakan kelas. Subjek penelitiannya adalah peserta didik kelas X-A MA Al Bidayah Candi Bandungan Kabupaten Semarang tahun pelajaran 2014/ 2015 sebanyak 20 peserta didik. Data dikumpulkan dengan metode dokumentasi, observasi, dan tes. Data yang terkumpul dianalisis menggunakan analisis deskriptif serta menentukan rata-rata hasil belajar dan persentase ketuntasan belajar.

Berdasarkan hasil penelitian, rata-rata hasil belajar dari siklus I ke siklus II meningkat dari 63,89 ke 83,13 atau sebesar 19,24 poin dan ketuntasan belajarnya meningkat dari $38,89 \%$ ke $80 \%$ atau sebesar 41,11\%. Penerapan model pembelajaran discovery learning berbantuan program Cabri 3D dapat meningkatkan hasil belajar peserta didik. Namun tidak serta merta dapat meningkatkan hasil belajar, karena hal ini dapat dipengaruhi oleh berbagai faktor seperti pengelolaan kelas, kemampuan peserta didik, konsentrasi peserta didik, ketelitian, dan sebagainya. Sehingga disarankan kepada guru agar melakukan pembelajaran inovatif, bervariasi, dan memanfaatkan media dalam menunjang proses pembelajaran.
\end{abstract}

Keywords: Discovery learning, cabri 3D, dimensi tiga 


\section{Pendahuluan}

Pembelajaran matematika pada jenjang pendidikan menengah mencakup materi yang lebih kompleks dan lebih rumit dibandingkan pada jejang pendidikan dasar. Peserta didik harus mampu mengabstarksi suatu model matematika dari permasalahan dimensi tiga yang diberikan, menerapkan konsep-konsep yang berhubungan, dan kemudian menyelesaikan permasalahan tersebut. Hal inilah yang kemudian menjadi kendala bagi peserta didik. Salah satunya adalah yang terjadi di MA Al Bidayah Candi Bandungan. Menurut Pujiati, salah seorang guru di madrasah tersebut, pada materi dimensi tiga, peserta didik mengalami kesulitan dalam menyelesaikan soal. Permasalahan itu diperjelas dengan masih banyaknya peserta didik yang belum mencapai KKM untuk materi dimensi tiga. Hasil ulangan harian dimensi tiga pada tahun pelajaran sebelumnya menunjukkan bahwa dari total 54 peserta didik kelas X, hanya ada 5 peserta didik yang tuntas, sedangkan rata-rata secara keseluruhan adalah 63,06.

Berdasarkan Laporan Hasil Ujian Nasional 2013/2014 oleh Badan Standar Nasional Pendidikan (BSNP), rata-rata hasil Ujian Nasional pada bidang studi matematika yang dicapai peserta didik jurusan Ilmu Pengetahuan Alam MA Al Bidayah adalah 4,56 dengan predikat D. Sedangkan persentase daya serap untuk kategori indikator materi ruang dimensi tiga, yaitu indikator menghitung jarak dan sudut antara dua objek (titik, garis dan bidang) di ruang dimensi tiga adalah 34,09\%. Hal ini menunjukkan bahwa pemahaman peserta didik di MA Al Bidayah pada materi ruang dimensi tiga masih kurang. 
Kesulitan itu disebabkan karena peserta didik belum menguasai konsep-konsep yang terdapat pada materi dimensi tiga. Selain itu peserta didik juga kesulitan dalam mengabstraksi model atau permasalahan yang diberikan pada dimensi tiga. Berdasarkan permasalahan tersebut, maka diperlukan solusi untuk mengatasi abstraksi dimensi tiga dan mempertajam konsep peserta didik. Salah satu upaya untuk mereduksi abstraksi adalah dengan memberikan visualisasi tiga dimensi kepada peserta didik melalui program Cabri 3D. Adapun salah satu solusi untuk mempertajam konsep materi adalah dengan memberikan pengalaman kepada siswa tentang konsep tersebut, dalam hal ini dilakukan melalui model pembelajaran Discovery Learning .

Penelitian ini dilakukan pada tahun pelajaran 2014/2015 untuk mengetahui apakah implementasi model pembelajaran Discovery Learning berbantuan Cabri 3D dapat meningkatkan hasil belajar pada materi Dimensi Tiga di MA Al Bidayah Candi Bandungan.

\section{Metode dan Hasil}

\section{Metode}

Jenis penelitian ini adalah penelitian tindakan kelas dengan dua siklus. Subjek penelitian adalah peserta didik kelas X-A MA Al Bidayah Candi Bandungan dan kolaborator Ibu Pujiati. Indikator keberhasilan yang digunakan adalah rata-rata hasil belajar peserta didik $\geq 75$ dan persentase ketuntasan hasil belajar secara klasikal minimal 75\% dari jumlah peserta didik yang mencapai KKM.

Data diambil dengan metode Dokumentasi, Observasi, dan Tes. Dokumentasi digunakan untuk mengambil data historis, observasi dilakukan untuk mengambil data aktivitas peserta didik dan pendidik, 
dan tes digunakan untuk mengambil data hasil belajar. Analisis data dilakukan dengan teknik rata-rata dan persentase.

\section{Hasil}

\section{Pra Siklus}

Analisis terhadap data pra siklus menunjukkan bahwa rata-rata hasil belajar peserta didik sebesar 63.06 dengan ketuntasan klasikan mencapai $9.26 \%$. Data ini menunjukkan capaian yang dibawah standar, yaitu persentase ketuntasan klasikal mencapai 75\% dengan KKM 75.

\section{Siklus I}

Pembelajaran siklus I dilakukan selama dua pertemuan pada materi menentukan jarak antara titik dengan titik dan menentukan jarak antara titik dengan garis. Pembelajaran dengan model discovery dilaksanakan dengan enam tahapan, yaitu stimulus, identifikasi masalah, pengupulan data, pengolahan data, verifikasi dan generalisasi. Pendidik menggunakan bantuan program Cabri 3D pada setiap tahapan discovery learning, kecuali generalisasi.

Hasil obeservasi menunjukkan bahwa peserta didik masih canggung dan malu untuk mengajukan pertanyaan dan dalam proses diskusi madih dibutuhkan pendampingan yang cukup banyak. Observasi terhadap pendidik menunjukkan bahwa karena perhatian guru terpecah dalam mendampingi, berakibat pada kurang optimalnya guru dalam melaksanakan tahapan identifikasi masalah, pengumpulan data dan generalisasi. Sedangkan hasil tes memberikan data rata-rata 
kelas sebesar 63.89, di bawah KKM dengan persentase ketuntasan sebesar 38.89\%. Selanjutnya berdasarkan hasil refleksi diputuskan bahwa perbaikan yang perlu dilakukan untuk siklus II adalah adanya reward bagi peserta didik yang aktif, bimbingan lebih optimal dalam pemecahan masalah dan manajemen waktu yang lebih baik.

\section{Siklus II}

Implementasi model pembelajaran Discovery Learning dengan bantuan Cabri 3D pada siklus II dilaksanakan pada materi menentukan jarak antara titik dengan bidang, dan menentukan jarak antara garis dengan garis. Sesuai dengan hasil refleksi, pada pembelajaran siklus II guru meningkatkan aktivitas bertanya peserta didik dengan pertanyaan pancingan dan pemberian reward. Hasil observasi menunjukkan peserta didik sudah mulai aktif dan mengikuti arahan dari guru, berani mengajukan pertanyaan, pendapat maupun sanggahannya.

\section{Pembahasan}

Berdasarkan analisis data dari setiap siklus, dapat dilihat bahwa terjadi peningkatan hasil belajar dari pra siklus, siklus I dan siklus II. Adanya peningkatan ini berawal dari perlakuan guru selama proses pembelajaran. Guru dengan menggunakan model pembelajaran discovery learning memberikan ruang kepada peserta didik untuk lebih aktif dalam bertanya dan mencari pemecahan masalah. Peningkatan ini sesuai dengan teori Bruner yang menyatakan bahwa belajar penemuan sesuai dengan proses pencarian pengetahuan yang aktif dilakukan oleh manusia, sehingga dengan sendirinya proses tersebut akan memberikan hasil yang terbaik. Hasil ini juga didukung dengan digunakannya program Cabri 3D, dimana 138 | 
dengan menggunakan media ini, maka peserta didik lebih terbantu dalam mengabstarksikan model dimensi tiga. Penggunaan media ini membantu peserta didik pada tahapan ikonik sesuai dengan tahapan pembelajaran dari Bruner. Kemudian, berkaitan dengan teori Van Hiele, selama proses pembelajaran, materi disusun dan disampaikan secara runtut sesuai dengan tingkatan geometri Van Hiele, sehingga peserta didik lebih mudah dalam menguasai materi yang disampaikan. Selain itu, guru juga membimbing peserta didik agar selalu mengaitkan materi yang akan dipelajari dengan materi yang telah dipelajari sebelumnya. Hal ini membantu peserta didik untuk lebih mudah dalam memahami materi yang disampaikan. Hal ini sesuai dengan teori yang dikemukakan oleh David Ausubel, yaitu konsep baru atau informasi baru harus dikaitkan dengan konsep-konsep yang sudah ada dalam struktur kognitif peserta didik. Dari ketiga teori tersebut, terbukti bahwa penggunaan model pembelajaran discovery learning dengan berbantuan program Cabri 3D pada materi dimensi tiga dapat mempengaruhi hasil belajar peserta didik kelas X-A MA Al Bidayah Candi Bandungan pada materi dimensi tiga, yaitu mengalami peningkatan pada setiap siklusnya.

\section{Penutup}

Model pembelajaran discovery learning memberikan ruang kepada peserta didik untuk lebih aktif dalam bertanya dan mencari pemecahan masalah. Lebih lengkapnya penggunaan model pembelajaran discovery learning dengan berbantuan program Cabri 3D pada materi dimensi tiga dapat mempengaruhi hasil belajar peserta didik kelas X-A MA Al Bidayah Candi Bandungan pada materi dimensi tiga, yaitu mengalami peningkatan pada setiap siklusnya.

\section{Referensi}

Hadi Prasetyo, Implementasi Discovery... 
Abdul Aziz dan Abdul Majid, At-Tarbiyah wa Turuqut Tadris, Mesir: Dani Ma’arif, 1979.

Accascina, Giuseppe dan Enrico Rogora, "Using Cabri 3D Diagrams for Teaching Geometry" dalam http://www.didmatcofin05.unimore.it/site/home/prodotti/prodot ti-2006/ documento15002331.pdf, diakses pada 15 Januari 2015 pukul 14.17 WIB.

Arikunto, Suharsimi, Prosedur Penelitian, Jakarta: Rineka Cipta, 2010.

Arikunto, Suharsimi, dkk., Penelitian Tindakan Kelas, Jakarta: Bumi Aksara, 2008.

BSNP, Hasil Laporan Ujian Nasional Tahun Pelajaran 2013/ 2014.

Dahar, Ratna Wilis, Teori-Teori Belajar dan Pembelajaran, Jakarta: Erlangga, 2011.

Dimyati dan Mudjiono, Belajar dan Pembelajaran, Jakarta: Rineka Cipta, 2006.

Echols, John M. dan Hasan Shadily, kamus Inggris Indonesia, Jakarta: PT. Gramedia, 2005.

Hamdani, Strategi Belajar Mengajar, Bandung: Pustaka Setia, 2011.

Hamzah, Ali, Perencanaan Dan Strategi Pembelajaran Matematika, Jakarta: Raja Grafindo Persada, 2014.

Komsiyah, Indah, Belajar dan Pembelajaran, Yogyakarta: Teras, 2012.

Mufarrokah, Anissatul, Strategi Belajar Mengajar, Yogyakarta: Teras, 2009.

Mulyasa, Guru Dalam Implementasi Kurikulum 2013, Bandung: Remaja Rosdakarya, 2014.

NK, Roestiyah, Strategi Belajar Mengajar, Jakarta: Rineka Cipta,2008.

Noor, Juliansyah, Metodologi Penelitian: Skripsi, Thesis, Disertasi, dan Karya Ilmiah, Jakarta: Kencana, 2011.

Pramudiyanti, Noviana, "Keefektifan Pembelajaran Model MMP Berbantuan Cabri 3D Terhadap Kemampuan Berpikir Kreatif Matematis Siswa Kelas X SMA Pada Materi Dimensi Tiga”, skripsi, 
Semarang: Fakultas Matematika dan Ilmu Pengetahuan Alam Universitas Negeri Semarang,2013.

Purwoko, "Teori Belajar Van Hiele" dalam http://staff.uny.ac.id/sites/default/files/PengembanganPembelajar anMatematika_UNIT_4_0.pdf, diakses pada 14 Desember 2014 pukul 12.25 WIB

Sam's, Rosma Hartiny, Model Penelitian Tindakan Kelas, Yogyakarta: Teras, 2010.

Saminanto, Ayo Praktik PTK, Semarang: Rasail, 2010.

Sudijono, Anas, Pengantar Evaluasi Pendidikan, Jakarta: Raja Grafindo Persada, 2009.

Sudjana, Metoda Statistika, Bandung: Tarsito, 2005.

Sugiarti, "Penggunaan Alat Peraga Model Luas Segitiga Dengan Metode Discovery (Penemuan) Untuk Meningkatkan Keaktifan Dan Hasil Belajar Peserta Didik Kelas Vii D Mtsn Sumber Pada Materi Pokok Luas Dan Keliling Segitiga", Skripsi, Semarang: Fakultas Tarbiyah IAIN Walisongo Semarang, 2010.

Suryabrata, Sumadi, Psikologi Pendidikan, Jakarta: Raja Grafindo Persada, 2004.

Sutjipto, Cecep Kustandi dan Bambang, Media Pembelajaran; Manual dan Digital, Bogor: Ghalia Indonesia, 2011.

Tampubolon, Saur, Penelitian Tindakan Kelas, Jakarta: Erlangga, 2014.

Trianto, Mendesain Model Pembelajaran Inovatif-Progresif, Jakarta: Prenada Media Group, 2009.

Undang-undang Nomor 20 Tahun 2003, Sistem Pendidikan Nasional

Van de Walle, John A., Matematika Sekolah Dasar dan Menengah jilid 2, Jakarta: Erlangga, 2012.

www.cabri.com

Hadi Prasetyo, Implementasi Discovery... 